\title{
International Regulatory Revelations of the Shadow Banking
}

\author{
Ping $\operatorname{Han}^{1}$ \\ ${ }^{1}$ School of Economics and Finance, Shandong Jiaotong University, Jinan, Shandong, China \\ Correspondence: Ping Han, School of Economics and Finance, Shandong Jiaotong University, Jinan, Shandong, \\ China. E-mail: vhanping@126.com
}

Received: November 20, 2014

Accepted: December 1, 2014

Online Published: December 8, 2014

doi:10.5430/afr.v4n1p54

URL: http://dx.doi.org/10.5430/afr.v4n1p54

\begin{abstract}
In recent years, the scale of shadow banking in China expands rapidly, which has great impact on the traditional commercial banks and the national economy. This also attracts attentions of policymakers and academic researchers. This paper discusses concept of shadow banking and, summarizes the main classification, composition and risks of shadow banking. Then, the paper compares regulations of shadow banking in the United States, Britain and European Union. Finally proposes some enlightenment from the shadow banking international regulatory practice.
\end{abstract}

Keywords: Shadow banking, International regulation, Enlightenment of supervision

\section{Introduction}

According to the definition of the financial stability board, the shadow banking refers to credit intermediaries who are free from the banking supervision system and could trigger a systemic risk and interest arbitrage. (Including all kinds of related institutions and business activities).

On a global scale, the "shadow banking" system mainly consists of four parts:

(1) The securitization enterprises whose main functions are securitization of traditional financial products.

(2) The marketed financial firms, including hedge funds, money market mutual funds, private equity funds, etc. They are mainly engaged in financing among traditional financial institutions and customers.

(3) The structured investment institutions

(4) The securities brokerage company.

Traditional banking system includes three participants: depositors, borrowers and banks. The shadow banking system also has three participants: depositors, borrowers and professional non-bank financial intermediaries (i.e., shadow Banks). Compared with the traditional banking system, in the shadow banking system, depositors do not save money in the bank but invest in mutual funds of money market and other similar funds. The borrowers get a loan too. Their fund comes not only from the depository institutions, but also from the comprehensive management of financial institutions. The shadow banking system also play a role of credit intermediary, but compared with the traditional banking system, its credit conversion process is much more complex.

\section{International regulation practice of shadow banking}

2.1 Shadow banking regulation of Major countries and organizations

2.1.1 supervision in the US

After the outbreak of the subprime crisis in 2007, the United States issued two financial regulatory reform bill, which are respectively "The Revolutionary Program of Financial System" by ministry of finance in March 2009 and "Dodd-Frank Act" by the congress in July 2010. "Dodd-Frank Act" contains a comprehensive regulation program of the shadow banking system. the main regulation related to the shadow banking system include:

(1) Perfect the relationship between commercial Banks and shadow Banks. Revising some acts related to banking, such as "the bank holding company act" in 1956. Strengthen supervision on banks' proprietary trading, off-balance sheet business, hedge funds and private equity fund. Government should bring commercial Banks' off-balance-sheet business into the scope of capital requirements. Also, government should define "off-balance-sheet" into 11 items, including direct credit substitutes and repurchase agreements, etc. 
(2) Perfect the process of clearing and bankrupt of shadow banking institutions. Detail documented progress of clearing and bankrupt of shadow banking institutions such as financial companies and brokers. Clearing system under responsibility of federal deposit Insurance Corporation is required to be established. The non-bank financial institutions bankruptcy procedures was discussed, and planed to modify the American bankruptcy law.

(3) The regulation of hedge funds and "Fannies and Freddie". "Private Equity Investment Adviser Registration Act" was promulgated in 2010. In this act, private equity firms like hedge funds are required to register, and disclose their trading information. They are also required to be checked regularly.

(4) Reduce transaction risks of securitization activities. Interest conflicts associated with particular securitization are revised. Bring asset-backed securities into the "securities and exchange act" of 1934, which will reduce the risk of arbitrage related to asset backed securities. The government also perfect process in regulation of asset-backed securities, such as increase retention of credit risk and financial risk, information disclosure, regulation on agents and guarantee in security issuance and due diligence, etc.

(5) Begin to pay close attention to the new derivatives. Studying the requirements of the approval procedure and function, require derivatives clearing organization to register, investigate data storage of swaps and other transactions.

\subsubsection{Supervision in the UK}

Since 2009, the British has also used crisis sweeping to reform the existing financial regulatory system, and launched regulation activities as to the shadow banking system.

Britain's financial services authority proposed "Turner report" in March 2009. This report documented that SIVs and other shadow banks have functions of match maturities and high leverage rate which are out of regulation and easy to cause systemic risk. Therefore, we should give recognition power of the shadow banking to regulators, and put the regulation of shadow banking into prudential regulation framework when necessary. A country's regulatory authority should strengthen cooperation with authorities in other countries in order to eliminate global interest arbitrage in regulation. Finally, the report indicated that hedge fund is not a kind of shadow banking, but regulators should put forward monitoring more information related to hedge funds, and determine whether they have systemic risk. In December 2009, Britain's Financial Services Authority (FSA) and the Ministry of Finance issued "Derivatives OTC Market Reform Act", strengthen the regulation of OTC derivatives market. In July 2010, the British Treasury submitted the "A New Method in Financial Regulation: Judgment, Emphases and Stabilization", put forward schemes to limit reserve of collateral haircuts in investment bank repo transactions as well as margin level in securities lending. It also made this scheme as a tool of potential macro-prudential regulation. In August 2010, Britain's financial services authority (FAS) submitted a discussion draft of "the system of trading behavior". The main content of it is to reduce the structural arbitrage between Banks and the shadow banking system. In February 2011, the British Treasury issued "a new path of the financial regulation: to build a more powerful system". This report put forward advices to revise "Britain's financial services and marketing" in 2000. Suggested to change the original tripartite regulatory system to establish a new financial regulatory body (financial policy committee (Financial Policy Committee FPC, Prudential Regulation Authorities PRA, Consumer Protection and Markets Authority CPMA). The report established a specific regulatory body to supervise shadow banking system.

In June 2011, the British Treasury issued a white paper-"A New Method of Financial Regulation: Framework of Reformation”. The content related to regulation of shadow banking including the following aspects:

(1)Assign FPC (Financial Policy Committee) suggest to the Treasury whether to strengthen or loose regulation to shadow banking institutions. When the shadow banking institutions or activity influence systemic risk, shadow banking institution or activities is transferred from securities regulators to PRA (prudential supervision authorities); conversely, when the activities are no longer a systemic risk, they are transferred from PRA to the securities regulatory authorities.

(2) Perfect the securities regulation. The paper proposed to revise unauthorized securities regulation in "company law" in 2006. Allowing the Treasury regulate unauthorized securities under the condition of no written contract deal. As to the "Investment Fund Managers Directive" of the European Union, the British government ensured to supervise in consistent with the international regulation on the hedge fund managers and private equity providers. Fund managers in a third country can enter the European Union with a passport. 


\subsubsection{Supervision in the European Union}

Since 2009, the European central bank constantly changed the laws of financial markets across the European. Items related to regulation of shadow banking including the following aspects:

(1) Modify directives on the alternative investment fund managers in April 2009, designed to improve the regulation and international coordination of its trading activities.

(2) In November 2009 and August 2010, the European central bank successively put forward some requirement related to the perfect of standards and risk weighting requirements on securitized assets.

(3) In April 2009 and October 2010, successively put forward measures to strengthen the regulation of credit rating agencies.

(4) In January 2011, put forward directives on strengthening of OTC derivatives and the regulation of trading storage.

(5) In March 2011, put forward directives to give certain rights to the European securities and markets authority and to perfect regulation on short selling and default swap.

(6) Issued in 2012 specific regulation plan on short selling and the credit default swap.

(7) At the end of 2012 launched specific regulation measures for OTC derivatives and trading storage.

2.2 comparison of shadow banking supervision in main countries

\subsection{1 features in common}

(1) All the regulation measures are not mean to forbid shadow banking business, but to eliminate defects in its operation. As to shadow banking business based on financial innovation, all countries haven't cancel them in their legislation, but gradually remove shadow banking system from the OTC to floor trading, intended to place them under regulation.

(2) All the regulation measures are committed to build a good supervision system, rather than compulsory regulation. A good supervision system is to encourage the development of financial markets, make efforts to reduce the friction, reduce the information asymmetry and reduce systemic risk in financial markets, rather than financial market on its own development. Reform of all countries is concern in reconstruction of financial regulation at the same time promote the market competition, this is for better development of financial market rather than curbing it.

(3) They all put the shadow banking system in the scope of global systemic risk regulatory. They all agreed with the regulation about systemically important financial institutions (SIFIs) proposed by the FSB, and committed to build dynamic macro-prudential regulation framework. All countries have not directly told about shadow banking in the periodic law of them, but put shadow banking into the SIFIs regulatory measures. SIFIs cover all financial institutions that may probably threaten financial system, including the shadow banking institutions. Regulation of SIFIs is a strategic reform measure as well as a new method to solve the old problem of "too big to fail".

\subsection{The differences of regulatory}

From the perspective of the regulation characteristics of the United States, due to the activities of the shadow banking system is basically in the OTC market, the main purpose of FED is to "see" the shadow banking activities clearly at the beginning of the crisis. To fully understand the shadow banking system, the regulators must let it out of the "shadow" into the sights of them. Regulators choose to bring shadow banking into floor market by the use of access, registration and drop out. After restricted basic business of shadow banking, regulators mean to make further reformations to perfect the operation of it. They are trying to change imperfect supervision into perfect one and finally minimize the systemic risk of shadow banking. All of these are to maintain steady operation of shadow banking.

Compared with the regulation in the United States, European countries focuses on supervision on global hedge fund transactions, because European countries are major buyers of Wall Street securities. They are counterparties of American shadow banking, and major buyers of securitized products. The main purpose of European countries regulation is trying to prevent infection of subprime mortgage products from the US. In addition to consistent with the EU regulation of hedge funds, the British authorities also specifically encourage financial service (product) competition and maintain transparency, encourage consumer protection as well as dynamically supervision on shadow banking instruments and activities according to financial services and instruments. The main reason of this kind of supervision is that shadow banking system is not fully developed in the UK. At the same time, loosen regulatory environment is in favor of consolidate the international financial centre status of London after the 
international financial crisis.

\section{Enlightenment of international shadow banking regulation}

Present situation and problems of the shadow banking system in our country are different compared with the main developed countries: first, the shadow banking system in China started late; it is small in scale compared with foreign countries. The operating mechanism is relatively simple and generally at early stage of development; Second, China's shadow banking system is different from developed countries like Europe and the United States which are characterized by high leverage wholesale funding. The shadow banking activities in our country are mainly credit financing, other off-balance sheet business and related products are gradually increasing. Also, the participate in shadow banking system in our country is numerous, the entire financial system correlation degree is high, blind expansion and irregular operation is common; Finally, part of the shadow banking in our country lack of clear legal norms and effective regulation.

According to the characteristics of shadow banking, draw lessons from the experience of international shadow banking supervision, strengthen the supervision of the shadow banking in our country should start from the following aspects.

\subsection{To establish and perfect the financial legislation about the shadow banking system}

At present, the people's bank of China, the China banking regulatory commission has launched a series of shadow banking regulation, but the relevant financial laws and regulations system is not completely cover the "shadow banking" or the "shadow banking activities". So, we need to strengthen and perfect bank financial products, folk financing, asset securitization, equity funds, OTC derivatives and other aspects of the laws and regulations. We should detail model requirements, specific institutional arrangements, provide legislative support and guide the orderly development.

\subsection{Properly handle the relationship between shadow banking innovation and regulation}

To further strengthen the financial innovation, effectively balance the financial innovation and financial regulation. Financial innovations play an important role on the development of financial industry. It is the power of financial reform, helpful in improving the financial service level, improving the international competitiveness of China's financial industry, and helpful in promoting the rapid development of the financial sectors.

Financial innovation is the main direction, but it must serve to the real economy as the basis. We should steadily develop financial innovation to serve the real economy. Fully develop positive role of shadow banking system as a useful supplement to the traditional financial system. Ensure the orderly conduct of financial innovation with comprehensive financial regulation, effective risk control. Also, we should continuously explore financial regulation and the balance between financial innovation, to realize the harmonious development of regulation and innovation; promote shadow banks steady, scientific development.

\subsection{To establish scientific examination evaluation system}

At the micro level, we should first strengthen the monitoring of shadow banking business in banks, such as finance, entrusted loans, collections, the collection of paper profit trust, etc. Secondly, we should strengthen monitoring on the transfer channel from shadow banking system to commercial banks, such as private equity financing, financing to non-financial lease company, guarantee company illegal lending, etc. Also, we should strengthen the regulation of OTC trading, regulate over-the-counter trading involving un-standardized OTC transaction.

At the macro level, we can measure from balance sheet and total social financing, to evaluate overall size and growth rate of financial assets in the shadow banking system. It can be compared with GDP, the money supply and other macroeconomic indicators, so as to understand its impact on the entire financial system and its influence to the systemic risk. Based on these two dimensions, we should also evaluate shadow banking activities from systemic risk and regulation escape, as to develop diverse, flexible and forward-looking regulation measures.

\subsection{To strengthen the built of the shadow banking corporate governance}

The principal-agent mechanism should be established, and clearing the power and responsibility between the board of directors and managers should be done. We should also strengthen the restriction on various governance bodies, clear-cut define the core position of corporate governance; strengthen the board's monitor on directors as to establish scientific director role and evaluation accountability.

Based on the incentive theory of corporate governance, dominated by bank value and development strategy, we should establish a market-oriented, long-term mechanism of incentive mechanism. Scientific and diversified mode of 
salary incentives should be established in order to realize match of salary with performance and risks.

We should strengthen disclosure work of all areas through regulation coordination. Especially, we should strengthen the construction of the banking industry's own firewall mechanism in order to fundamentally improve the degree of information disclosure of the shadow banking system. Information asymmetry between Banks and investors should be reduced s far as possible. At the same time, the bank regulator should improve regulatory transparency in order to establish and improve the triggering mechanism and to curb financial market participants from excessive profit-perusing and short-term behavior which ignore the potential risks.

\section{References}

Adrian, T., Shin H. (2010). The Changing Nature of Financial Intermediation and the Financial Crisis of 2007-09. Federal Reserve Bank of New York Staff Reports. http://dx.doi.org/10.2139/ssrn.1576590

Chen Nanhui. (2012). Shadow banking regulation of international experience and enlightenment to China. Journal of Wuhan University of technology. 2012, 12.

Cai Jing. (2012). International shadow banking regulatory reform and enlightenment.Qinghai financial. 2012,06

FSB. (2011). Shadow Banking Strengthening Oversight and Regulation.October,2011, 10.

Gong Minghua, Zhang Xiaopiao, Wen Zhu. (2011). shadow banking and regulatory risk. China's financial..

GuXiuJun. (2013). Shadow banking and regulation of forms of expression. China's financial. 2013, 05.

Hu Song. (2013). International shadow banking supervision system of our country's enlightenment. Financial era of science and technology. 2013, 08.

Li Dongwei. (2011). The shadow banking system of supervision and management. The central committee of the communist party of China party school journal, 2011, 04.

PengJiangcai. (2013). China's shadow banking system regulation law thinking. Journal of Hubei police academy. 2013, 05.

XinQiao Li. (2010). Shadow banking: reveal a little-known financial black hole. Beijing: China economic publishing house. 2010, 01.

Zhou Liping. (2012). Concerning the progress of the international regulation of shadow banking system, insufficient, way out. International financial research. 2012, 01. 